\title{
Three Women's Texts and a Critique of Imperialism
}

\section{Gayatri Chakravorty Spivak}

It should not be possible to read nineteenth-century British literature without remembering that imperialism, understood as England's social mission, was a crucial part of the cultural representation of England to the English. The role of literature in the production of cultural representation should not be ignored. These two obvious "facts" continue to be disregarded in the reading of nineteenth-century British literature. This itself attests to the continuing success of the imperialist project, displaced and dispersed into more modern forms.

If these "facts" were remembered, not only in the study of British literature but in the study of the literatures of the European colonizing cultures of the great age of imperialism, we would produce a narrative, in literary history, of the "worlding" of what is now called "the Third World." To consider the Third World as distant cultures, exploited but with rich intact literary heritages waiting to be recovered, interpreted, and curricularized in English translation fosters the emergence of "the Third World" as a signifier that allows us to forget that "worlding," even as it expands the empire of the literary discipline. ${ }^{1}$

It seems particularly unfortunate when the emergent perspective of feminist criticism reproduces the axioms of imperialism. A basically isolationist admiration for the literature of the female subject in Europe and Anglo-America establishes the high feminist norm. It is supported and operated by an information-retrieval approach to "Third World" literature which often employs a deliberately "nontheoretical" methodology with self-conscious rectitude. 
In this essay, I will attempt to examine the operation of the "worlding" of what is today "the Third World" by what has become a cult text of feminism: Jane Eyre. ${ }^{2}$ I plot the novel's reach and grasp, and locate its structural motors. I read Wide Sargasso Sea as Jane Eyre's reinscription and Frankenstein as an analysis - even a deconstruction-of a "worlding" such as Jane Eyre's. ${ }^{3}$

I need hardly mention that the object of my investigation is the printed book, not its "author." To make such a distinction is, of course, to ignore the lessons of deconstruction. A deconstructive critical approach would loosen the binding of the book, undo the opposition between verbal text and the bio-graphy of the named subject "Charlotte Brontë," and see the two as each other's "scene of writing." In such a reading, the life that writes itself as "my life" is as much a production in psychosocial space (other names can be found) as the book that is written by the holder of that named life - a book that is then consigned to what is most often recognized as genuinely "social": the world of publication and distribution. ${ }^{4}$ To touch Brontë's "life" in such a way, however, would be too risky here. We must rather strategically take shelter in an essentialism which, not wishing to lose the important advantages won by U.S. mainstream feminism, will continue to honor the suspect binary oppositions book and author, individual and history-and start with an assurance of the following sort: my readings here do not seek to undermine the excellence of the individual artist. If even minimally successful, the readings will incite a degree of rage against the imperialist narrativization of history, that it should produce so abject a script for her. I provide these assurances to allow myself some room to situate feminist individualism in its historical determination rather than simply to canonize it as feminism as such.

Sympathetic U.S. feminists have remarked that I do not do justice to Jane Eyre's subjectivity. A word of explanation is perhaps in order. The broad strokes of my presuppositions are that what is at stake, for feminist individualism in the age of imperialism, is precisely the making of human beings, the constitution and "interpellation" of the subject not only as individual but as "individualist." This stake is represented on two registers: childbearing and soul making. The first is domestic-societythrough-sexual-reproduction cathected as "companionate love"; the second is the imperialist project cathected as civil-society-through-social-mission. As the female individualist, not-quite/not-male, articulates herself in shifting

Gayatri Chakravorty Spivak is Longstreet Professor of English at Emory University. She is the translator of Jacques Derrida's De la grammatologie and is presently finishing a book entitled Master Discourse, Native Informant. Her previous contributions to Critical Inquiry are " 'Draupadi' by Mahasveta Devi” (Winter 1981) and “The Politics of Interpretations" (September 1982). 
relationship to what is at stake, the "native female" as such (within discourse, as a signifier) is excluded from any share in this emerging norm. ${ }^{6}$ If we read this account from an isolationist perspective in a "metropolitan" context, we see nothing there but the psychobiography of the militant female subject. In a reading such as mine, in contrast, the effort is to wrench oneself away from the mesmerizing focus of the "subject-constitution" of the female individualist.

To develop further the notion that my stance need not be an accusing one, I will refer to a passage from Roberto Fernández Retamar's "Caliban.." José Enrique Rodó had argued in 1900 that the model for the Latin American intellectual in relationship to Europe could be Shakespeare's Ariel. ${ }^{8}$ In 1971 Retamar, denying the possibility of an identifiable "Latin American Culture," recast the model as Caliban. Not surprisingly, this powerful exchange still excludes any specific consideration of the civilizations of the Maya, the Aztecs, the Incas, or the smaller nations of what is now called Latin America. Let us note carefully that, at this stage of my argument, this "conversation" between Europe and Latin America (without a specific consideration of the political economy of the "worlding" of the "native") provides a sufficient thematic description of our attempt to confront the ethnocentric and reverse-ethnocentric benevolent double bind (that is, considering the "native" as object for enthusiastic informationretrieval and thus denying its own "worlding") that I sketched in my opening paragraphs.

In a moving passage in "Caliban," Retamar locates both Caliban and Ariel in the postcolonial intellectual:

There is no real Ariel-Caliban polarity: both are slaves in the hands of Prospero, the foreign magician. But Caliban is the rude and unconquerable master of the island, while Ariel, a creature of the air, although also a child of the isle, is the intellectual.

The deformed Caliban-enslaved, robbed of his island, and taught the language by Prospero-rebukes him thus: "You taught me language, and my profit on't / Is, I know how to curse." [“C,” pp. 28, 11]

As we attempt to unlearn our so-called privilege as Ariel and "seek from [a certain] Caliban the honor of a place in his rebellious and glorious ranks," we do not ask that our students and colleagues should emulate us but that they should attend to us ("C," p. 72). If, however, we are driven by a nostalgia for lost origins, we too run the risk of effacing the "native" and stepping forth as "the real Caliban," of forgetting that he is a name in a play, an inaccessible blankness circumscribed by an interpretable text. ${ }^{9}$ The stagings of Caliban work alongside the narrativization of history: claiming to be Caliban legitimizes the very individualism that we must persistently attempt to undermine from within. 
Elizabeth Fox-Genovese, in an article on history and women's history, shows us how to define the historical moment of feminism in the West in terms of female access to individualism. ${ }^{10}$ The battle for female individualism plays itself out within the larger theater of the establishment of meritocratic individualism, indexed in the aesthetic field by the ideology of "the creative imagination." Fox-Genovese's presupposition will guide us into the beautifully orchestrated opening of Jane Eyre.

It is a scene of the marginalization and privatization of the protagonist: "There was no possibility of taking a walk that day. . . . Out-door exercise was now out of the question. I was glad of it," Brontë writes (JE, p. 9). The movement continues as Jane breaks the rules of the appropriate topography of withdrawal. The family at the center withdraws into the sanctioned architectural space of the withdrawing room or drawing room; Jane inserts herself - "I slipped in"-into the margin - "A small breakfastroom adjoined the drawing room" ( $J E$, p. 9; my emphasis).

The manipulation of the domestic inscription of space within the upwardly mobilizing currents of the eighteenth- and nineteenth-century bourgeoisie in England and France is well known. It seems fitting that the place to which Jane withdraws is not only not the withdrawing room but also not the dining room, the sanctioned place of family meals. Nor is it the library, the appropriate place for reading. The breakfast room "contained a book-case" ( $J E$, p. 9). As Rudolph Ackerman wrote in his Repository (1823), one of the many manuals of taste in circulation in nineteenth-century England, these low bookcases and stands were designed to "contain all the books that may be desired for a sitting-room without reference to the library."11 Even in this already triply off-center place, "having drawn the red moreen curtain nearly close, I [ Jane] was shrined in double retirement" ( $J E$, pp. 9-10).

Here in Jane's self-marginalized uniqueness, the reader becomes her accomplice: the reader and Jane are united-both are reading. Yet Jane still preserves her odd privilege, for she continues never quite doing the proper thing in its proper place. She cares little for reading what is meant to be read: the "letter-press." She reads the pictures. The power of this singular hermeneutics is precisely that it can make the outside inside. "At intervals, while turning over the leaves of my book, I studied the aspect of that winter afternoon." Under "the clear panes of glass," the rain no longer penetrates, "the drear November day" is rather a onedimensional "aspect" to be "studied," not decoded like the "letter-press" but, like pictures, deciphered by the unique creative imagination of the marginal individualist ( $J E$, p. 10).

Before following the track of this unique imagination, let us consider the suggestion that the progress of Jane Eyre can be charted through a sequential arrangement of the family/counter-family dyad. In the novel, we encounter, first, the Reeds as the legal family and Jane, the late Mr. Reed's sister's daughter, as the representative of a near incestuous counter- 
family; second, the Brocklehursts, who run the school Jane is sent to, as the legal family and Jane, Miss Temple, and Helen Burns as a counterfamily that falls short because it is only a community of women; third, Rochester and the mad Mrs. Rochester as the legal family and Jane and Rochester as the illicit counter-family. Other items may be added to the thematic chain in this sequence: Rochester and Céline Varens as structurally functional counter-family; Rochester and Blanche Ingram as dissimulation of legality-and so on. It is during this sequence that Jane is moved from the counter-family to the family-in-law. In the next sequence, it is Jane who restores full family status to the as-yet-incomplete community of siblings, the Riverses. The final sequence of the book is a community of families, with Jane, Rochester, and their children at the center.

In terms of the narrative energy of the novel, how is Jane moved from the place of the counter-family to the family-in-law? It is the active ideology of imperialism that provides the discursive field.

(My working definition of "discursive field" must assume the existence of discrete "systems of signs" at hand in the socius, each based on a specific axiomatics. I am identifying these systems as discursive fields. "Imperialism as social mission" generates the possibility of one such axiomatics. How the individual artist taps the discursive field at hand with a sure touch, if not with transhistorical clairvoyance, in order to make the narrative structure move I hope to demonstrate through the following example. It is crucial that we extend our analysis of this example beyond the minimal diagnosis of "racism.")

Let us consider the figure of Bertha Mason, a figure produced by the axiomatics of imperialism. Through Bertha Mason, the white Jamaican Creole, Brontë renders the human/animal frontier as acceptably indeterminate, so that a good greater than the letter of the Law can be broached. Here is the celebrated passage, given in the voice of Jane:

In the deep shade, at the further end of the room, a figure ran backwards and forwards. What it was, whether beast or human being, one could not ... tell: it grovelled, seemingly, on all fours; it snatched and growled like some strange wild animal: but it was covered with clothing, and a quantity of dark, grizzled hair, wild as a mane, hid its head and face. [JE, p. 295]

In a matching passage, given in the voice of Rochester speaking to Jane, Brontë presents the imperative for a shift beyond the Law as divine injunction rather than human motive. In the terms of my essay, we might say that this is the register not of mere marriage or sexual reproduction but of Europe and its not-yet-human Other, of soul making. The field of imperial conquest is here inscribed as Hell:

"One night I had been awakened by her yells ... it was a fiery West Indian night.... 
“'This life,' said I at last, 'is hell! - this is the air-those are the sounds of the bottomless pit! I have a right to deliver myself from it if I can. . . . Let me break away, and go home to God!' . . .

"A wind fresh from Europe blew over the ocean and rushed through the open casement: the storm broke, streamed, thundered, blazed, and the air grew pure. ... It was true Wisdom that consoled me in that hour, and showed me the right path. ...

"The sweet wind from Europe was still whispering in the refreshed leaves, and the Atlantic was thundering in glorious liberty. . . .

" 'Go,' said Hope, 'and live again in Europe. . . . You have done all that God and Humanity require of you." [ $J E$, pp. 310-11; my emphasis]

It is the unquestioned ideology of imperialist axiomatics, then, that conditions Jane's move from the counter-family set to the set of the family-in-law. Marxist critics such as Terry Eagleton have seen this only in terms of the ambiguous class position of the governess. ${ }^{12}$ Sandra Gilbert and Susan Gubar, on the other hand, have seen Bertha Mason only in psychological terms, as Jane's dark double. ${ }^{13}$

I will not enter the critical debates that offer themselves here. Instead, I will develop the suggestion that nineteenth-century feminist individualism could conceive of a "greater" project than access to the closed circle of the nuclear family. This is the project of soul making beyond "mere" sexual reproduction. Here the native "subject" is not almost an animal but rather the object of what might be termed the terrorism of the categorical imperative.

I am using "Kant" in this essay as a metonym for the most flexible ethical moment in the European eighteenth century. Kant words the categorical imperative, conceived as the universal moral law given by pure reason, in this way: "In all creation every thing one chooses and over which one has any power, may be used merely as means; man alone, and with him every rational creature, is an end in himself." It is thus a moving displacement of Christian ethics from religion to philosophy. As Kant writes: "With this agrees very well the possibility of such a command as: Love God above everything, and thy neighbor as thyself. For as a command it requires respect for a law which commands love and does not leave it to our own arbitrary choice to make this our principle."14

The "categorical" in Kant cannot be adequately represented in determinately grounded action. The dangerous transformative power of philosophy, however, is that its formal subtlety can be travestied in the service of the state. Such a travesty in the case of the categorical imperative can justify the imperialist project by producing the following formula: make the heathen into a human so that he can be treated as an end in himself. ${ }^{15}$ This project is presented as a sort of tangent in Jane Eyre, a tangent that escapes the closed circle of the narrative conclusion. The 
tangent narrative is the story of St. John Rivers, who is granted the important task of concluding the text.

At the novel's end, the allegorical language of Christian psychobiography-rather than the textually constituted and seemingly private grammar of the creative imagination which we noted in the novel's opening-marks the inaccessibility of the imperialist project as such to the nascent "feminist" scenario. The concluding passage of Jane Eyre places St. John Rivers within the fold of Pilgrim's Progress. Eagleton pays no attention to this but accepts the novel's ideological lexicon, which establishes St. John Rivers' heroism by identifying a life in Calcutta with an unquestioning choice of death. Gilbert and Gubar, by calling Jane Eyre "Plain Jane's progress," see the novel as simply replacing the male protagonist with the female. They do not notice the distance between sexual reproduction and soul making, both actualized by the unquestioned idiom of imperialist presuppositions evident in the last part of Jane Eyre:

Firm, faithful, and devoted, full of energy, and zeal, and truth, [St. John Rivers] labours for his race.... His is the sternness of the warrior Greatheart, who guards his pilgrim convoy from the onslaught of Apollyon. ... His is the ambition of the high master-spirit[s] . . who stand without fault before the throne of God; who share the last mighty victories of the Lamb; who are called, and chosen, and faithful. [JE, p. 455]

Earlier in the novel, St. John Rivers himself justifies the project: "My vocation? My great work? . . My hopes of being numbered in the band who have merged all ambitions in the glorious one of bettering their race-of carrying knowledge into the realms of ignorance-of substituting peace for war-freedom for bondage-religion for superstition-the hope of heaven for the fear of hell?" ( $J E$, p. 376). Imperialism and its territorial and subject-constituting project are a violent deconstruction of these oppositions.

When Jean Rhys, born on the Caribbean island of Dominica, read Jane Eyre as a child, she was moved by Bertha Mason: "I thought I'd try to write her a life." ${ }^{16}$ Wide Sargasso Sea, the slim novel published in 1965, at the end of Rhys' long career, is that "life."

I have suggested that Bertha's function in Jane Eyre is to render indeterminate the boundary between human and animal and thereby to weaken her entitlement under the spirit if not the letter of the Law. When Rhys rewrites the scene in Jane Eyre where Jane hears "a snarling, snatching sound, almost like a dog quarrelling" and then encounters a bleeding Richard Mason ( $J E$, p. 210), she keeps Bertha's humanity, indeed her sanity as critic of imperialism, intact. Grace Poole, another character originally in Jane Eyre, describes the incident to Bertha in Wide Sargasso Sea: "So you don't remember that you attacked this gentleman with a 
knife? .. . I didn't hear all he said except 'I cannot interfere legally between yourself and your husband'. It was when he said 'legally' that you flew at him' " (WSS, p. 150). In Rhys' retelling, it is the dissimulation that Bertha discerns in the word "legally" - not an innate bestiality-that prompts her violent reaction.

In the figure of Antoinette, whom in Wide Sargasso Sea Rochester violently renames Bertha, Rhys suggests that so intimate a thing as personal and human identity might be determined by the politics of imperialism. Antoinette, as a white Creole child growing up at the time of emancipation in Jamaica, is caught between the English imperialist and the black native. In recounting Antoinette's development, Rhys reinscribes some thematics of Narcissus.

There are, noticeably, many images of mirroring in the text. I will quote one from the first section. In this passage, Tia is the little black servant girl who is Antoinette's close companion: "We had eaten the same food, slept side by side, bathed in the same river. As I ran, I thought, I will live with Tia and I will be like her.... When I was close I saw the jagged stone in her hand but I did not see her throw it.... We stared at each other, blood on my face, tears on hers. It was as if I saw myself. Like in a looking glass" (WSS, p. 38).

A progressive sequence of dreams reinforces this mirror imagery. In its second occurrence, the dream is partially set in a hortus conclusus, or "enclosed garden"-Rhys uses the phrase (WSS, p. 50)-a Romance rewriting of the Narcissus topos as the place of encounter with Love. ${ }^{17}$ In the enclosed garden, Antoinette encounters not Love but a strange threatening voice that says merely "in here," inviting her into a prison which masquerades as the legalization of love (WSS, p. 50).

In Ovid's Metamorphoses, Narcissus' madness is disclosed when he recognizes his Other as his self: "Iste ego sum.." ${ }^{18}$ Rhys makes Antoinette see her self as her Other, Brontë's Bertha. In the last section of Wide Sargasso Sea, Antoinette acts out Jane Eyre's conclusion and recognizes herself as the so-called ghost in Thornfield Hall: "I went into the hall again with the tall candle in my hand. It was then that I saw her-the ghost. The woman with streaming hair. She was surrounded by a gilt frame but I knew her" (WSS, p. 154). The gilt frame encloses a mirror: as Narcissus' pool reflects the selfed Other, so this "pool" reflects the Othered self. Here the dream sequence ends, with an invocation of none other than Tia, the Other that could not be selfed, because the fracture of imperialism rather than the Ovidian pool intervened. (I will return to this difficult point.) "That was the third time I had my dream, and it ended. ... I called 'Tia' and jumped and woke" (WSS, p. 155). It is now, at the very end of the book, that Antoinette/Bertha can say: "Now at last I know why I was brought here and what I have to do" (WSS, pp. 15556). We can read this as her having been brought into the England of Brontë's novel: "This cardboard house"-a book between cardboard cov- 
ers - "where I walk at night is not England" (WSS, p. 148). In this fictive England, she must play out her role, act out the transformation of her "self" into that fictive Other, set fire to the house and kill herself, so that Jane Eyre can become the feminist individualist heroine of British fiction. I must read this as an allegory of the general epistemic violence of imperialism, the construction of a self-immolating colonial subject for the glorification of the social mission of the colonizer. At least Rhys sees to it that the woman from the colonies is not sacrificed as an insane animal for her sister's consolidation.

Critics have remarked that Wide Sargasso Sea treats the Rochester character with understanding and sympathy. ${ }^{19}$ Indeed, he narrates the entire middle section of the book. Rhys makes it clear that he is a victim of the patriarchal inheritance law of entailment rather than of a father's natural preference for the firstborn: in Wide Sargasso Sea, Rochester's situation is clearly that of a younger son dispatched to the colonies to buy an heiress. If in the case of Antoinette and her identity, Rhys utilizes the thematics of Narcissus, in the case of Rochester and his patrimony, she touches on the thematics of Oedipus. (In this she has her finger on our "historical moment." If, in the nineteenth century, subject-constitution is represented as childbearing and soul making, in the twentieth century psychoanalysis allows the West to plot the itinerary of the subject from Narcissus [the "imaginary"] to Oedipus [the "symbolic"]. This subject, however, is the normative male subject. In Rhys' reinscription of these themes, divided between the female and the male protagonist, feminism and a critique of imperialism become complicit.)

In place of the "wind from Europe" scene, Rhys substitutes the scenario of a suppressed letter to a father, a letter which would be the "correct" explanation of the tragedy of the book. ${ }^{20}$ "I thought about the letter which should have been written to England a week ago. Dear Father ..." (WSS, p. 57). This is the first instance: the letter not written. Shortly afterward:

Dear Father. The thirty thousand pounds have been paid to me without question or condition. No provision made for her (that must be seen to). . . . I will never be a disgrace to you or to my dear brother the son you love. No begging letters, no mean requests. None of the furtive shabby manoeuvres of a younger son. I have sold my soul or you have sold it, and after all is it such a bad bargain? The girl is thought to be beautiful, she is beautiful. And yet ... [WSS, p. 59]

This is the second instance: the letter not sent. The formal letter is uninteresting; I will quote only a part of it:

Dear Father, we have arrived from Jamaica after an uncomfortable few days. This little estate in the Windward Islands is part of the 
family property and Antoinette is much attached to it. ... All is well and has gone according to your plans and wishes. I dealt of course with Richard Mason. ... . He seemed to become attached to me and trusted me completely. This place is very beautiful but my illness has left me too exhausted to appreciate it fully. I will write again in a few days' time. [WSS, p. 63]

\section{And so on.}

Rhys' version of the Oedipal exchange is ironic, not a closed circle. We cannot know if the letter actually reaches its destination. "I wondered how they got their letters posted," the Rochester figure muses. "I folded mine and put it into a drawer of the desk. . . There are blanks in my mind that cannot be filled up" (WSS, p. 64). It is as if the text presses us to note the analogy between letter and mind.

Rhys denies to Brontë's Rochester the one thing that is supposed to be secured in the Oedipal relay: the Name of the Father, or the patronymic. In Wide Sargasso Sea, the character corresponding to Rochester has no name. His writing of the final version of the letter to his father is supervised, in fact, by an image of the loss of the patronymic: "There was a crude bookshelf made of three shingles strung together over the desk and I looked at the books, Byron's poems, novels by Sir Walter Scott, Confessions of an Opium Eater . . . and on the last shelf, Life and Letters of . . . The rest was eaten away" (WSS, p. 63).

Wide Sargasso Sea marks with uncanny clarity the limits of its own discourse in Christophine, Antoinette's black nurse. We may perhaps surmise the distance between Jane Eyre and Wide Sargasso Sea by remarking that Christophine's unfinished story is the tangent to the latter narrative, as St. John Rivers' story is to the former. Christophine is not a native of Jamaica; she is from Martinique. Taxonomically, she belongs to the category of the good servant rather than that of the pure native. But within these borders, Rhys creates a powerfully suggestive figure.

Christophine is the first interpreter and named speaking subject in the text. "The Jamaican ladies had never approved of my mother, 'because she pretty like pretty self' Christophine said," we read in the book's opening paragraph (WSS, p. 15). I have taught this book five times, once in France, once to students who had worked on the book with the wellknown Caribbean novelist Wilson Harris, and once at a prestigious institute where the majority of the students were faculty from other universities. It is part of the political argument I am making that all these students blithely stepped over this paragraph without asking or knowing what Christophine's patois, so-called incorrect English, might mean.

Christophine is, of course, a commodified person. "She was your father's wedding present to me' " explains Antoinette's mother, “'one of his presents'” (WSS, p. 18). Yet Rhys assigns her some crucial functions in the text. It is Christophine who judges that black ritual practices are 
culture-specific and cannot be used by whites as cheap remedies for social evils, such as Rochester's lack of love for Antoinette. Most important, it is Christophine alone whom Rhys allows to offer a hard analysis of Rochester's actions, to challenge him in a face-to-face encounter. The entire extended passage is worthy of comment. I quote a brief extract:

"She is Creole girl, and she have the sun in her. Tell the truth now. She don't come to your house in this place England they tell me about, she don't come to your beautiful house to beg you to marry with her. No, it's you come all the long way to her house-it's you beg her to marry. And she love you and she give you all she have. Now you say you don't love her and you break her up. What you do with her money, eh?" [And then Rochester, the white man, comments silently to himself] Her voice was still quiet but with a hiss in it when she said "money." [WSS, p. 130]

Her analysis is powerful enough for the white man to be afraid: "I no longer felt dazed, tired, half hypnotized, but alert and wary, ready to defend myself" (WSS, p. 130).

Rhys does not, however, romanticize individual heroics on the part of the oppressed. When the Man refers to the forces of Law and Order, Christophine recognizes their power. This exposure of civil inequality is emphasized by the fact that, just before the Man's successful threat, Christophine had invoked the emancipation of slaves in Jamaica by proclaiming: "No chain gang, no tread machine, no dark jail either. This is free country and I am free woman" (WSS, p. 131).

As I mentioned above, Christophine is tangential to this narrative. She cannot be contained by a novel which rewrites a canonical English text within the European novelistic tradition in the interest of the white Creole rather than the native. No perspective critical of imperialism can turn the Other into a self, because the project of imperialism has always already historically refracted what might have been the absolutely Other into a domesticated Other that consolidates the imperialist self. ${ }^{21}$ The Caliban of Retamar, caught between Europe and Latin America, reflects this predicament. We can read Rhys' reinscription of Narcissus as a thematization of the same problematic.

Of course, we cannot know Jean Rhys' feelings in the matter. We can, however, look at the scene of Christophine's inscription in the text. Immediately after the exchange between her and the Man, well before the conclusion, she is simply driven out of the story, with neither narrative nor characterological explanation or justice. " 'Read and write I don't know. Other things I know.' She walked away without looking back” (WSS, p. 133).

Indeed, if Rhys rewrites the madwoman's attack on the Man by underlining of the misuse of "legality," she cannot deal with the passage 
that corresponds to St. John Rivers' own justification of his martyrdom, for it has been displaced into the current idiom of modernization and development. Attempts to construct the "Third World Woman" as a signifier remind us that the hegemonic definition of literature is itself caught within the history of imperialism. A full literary reinscription cannot easily flourish in the imperialist fracture or discontinuity, covered over by an alien legal system masquerading as Law as such, an alien ideology established as only Truth, and a set of human sciences busy establishing the "native" as self-consolidating Other.

In the Indian case at least, it would be difficult to find an ideological clue to the planned epistemic violence of imperialism merely by rearranging curricula or syllabi within existing norms of literary pedagogy. For a later period of imperialism - when the constituted colonial subject has firmly taken hold-straightforward experiments of comparison can be undertaken, say, between the functionally witless India of Mrs. Dalloway, on the one hand, and literary texts produced in India in the 1920s, on the other. But the first half of the nineteenth century resists questioning through literature or literary criticism in the narrow sense, because both are implicated in the project of producing Ariel. To reopen the fracture without succumbing to a nostalgia for lost origins, the literary critic must turn to the archives of imperial governance.

In conclusion, I shall look briefly at Mary Shelley's Frankenstein, a text of nascent feminism that remains cryptic, I think, simply because it does not speak the language of feminist individualism which we have come to hail as the language of high feminism within English literature. It is interesting that Barbara Johnson's brief study tries to rescue this recalcitrant text for the service of feminist autobiography. ${ }^{22}$ Alternatively, George Levine reads Frankenstein in the context of the creative imagination and the nature of the hero. He sees the novel as a book about its own writing and about writing itself, a Romantic allegory of reading within which Jane Eyre as unself-conscious critic would fit quite nicely. ${ }^{23}$

I propose to take Frankenstein out of this arena and focus on it in terms of that sense of English cultural identity which I invoked at the opening of this essay. Within that focus we are obliged to admit that, although Frankenstein is ostensibly about the origin and evolution of man in society, it does not deploy the axiomatics of imperialism.

Let me say at once that there is plenty of incidental imperialist sentiment in Frankenstein. My point, within the argument of this essay, is that the discursive field of imperialism does not produce unquestioned ideological correlatives for the narrative structuring of the book. The discourse of imperialism surfaces in a curiously powerful way in Shelley's novel, and I will later discuss the moment at which it emerges.

Frankenstein is not a battleground of male and female individualism articulated in terms of sexual reproduction (family and female) and social subject-production (race and male). That binary opposition is undone 
in Victor Frankenstein's laboratory-an artificial womb where both projects are undertaken simultaneously, though the terms are never openly spelled out. Frankenstein's apparent antagonist is God himself as Maker of Man, but his real competitor is also woman as the maker of children. It is not just that his dream of the death of mother and bride and the actual death of his bride are associated with the visit of his monstrous homoerotic "son" to his bed. On a much more overt level, the monster is a bodied "corpse," unnatural because bereft of a determinable childhood: "No father had watched my infant days, no mother had blessed me with smiles and caresses; or if they had, all my past was now a blot, a blind vacancy in which I distinguished nothing" ( $F$, pp. 57, 115). It is Frankenstein's own ambiguous and miscued understanding of the real motive for the monster's vengefulness that reveals his own competition with woman as maker:

I created a rational creature and was bound towards him to assure, as far as was in my power, his happiness and well-being. This was my duty, but there was another still paramount to that. My duties towards the beings of my own species had greater claims to my attention because they included a greater proportion of happiness or misery. Urged by this view, I refused, and I did right in refusing, to create a companion for the first creature. $[F$, p. 206]

It is impossible not to notice the accents of transgression inflecting Frankenstein's demolition of his experiment to create the future Eve. Even in the laboratory, the woman-in-the-making is not a bodied corpse but "a human being." The (il)logic of the metaphor bestows on her a prior existence which Frankenstein aborts, rather than an anterior death which he reembodies: "The remains of the half-finished creature, whom I had destroyed, lay scattered on the floor, and I almost felt as if I had mangled the living flesh of a human being" $(F$, p. 163).

In Shelley's view, man's hubris as soul maker both usurps the place of God and attempts - vainly — to sublate woman's physiological prerogative.$^{24}$ Indeed, indulging a Freudian fantasy here, I could urge that, if to give and withhold to/from the mother a phallus is the male fetish, then to give and withhold to/from the man a womb might be the female fetish. ${ }^{25}$ The icon of the sublimated womb in man is surely his productive brain, the box in the head.

In the judgment of classical psychoanalysis, the phallic mother exists only by virtue of the castration-anxious son; in Frankenstein's judgment, the hysteric father (Victor Frankenstein gifted with his laboratory-the womb of theoretical reason) cannot produce a daughter. Here the language of racism-the dark side of imperialism understood as social missioncombines with the hysteria of masculism into the idiom of (the withdrawal of) sexual reproduction rather than subject-constitution. The roles of 
masculine and feminine individualists are hence reversed and displaced. Frankenstein cannot produce a "daughter" because "she might become ten thousand times more malignant than her mate ... [and because] one of the first results of those sympathies for which the demon thirsted would be children, and a race of devils would be propagated upon the earth who might make the very existence of the species of man a condition precarious and full of terror" $(F, p .158)$. This particular narrative strand also launches a thoroughgoing critique of the eighteenth-century European discourses on the origin of society through (Western Christian) man. Should I mention that, much like Jean-Jacques Rousseau's remark in his Confessions, Frankenstein declares himself to be "by birth a Genevese" ( $F$, p. 31)?

In this overly didactic text, Shelley's point is that social engineering should not be based on pure, theoretical, or natural-scientific reason alone, which is her implicit critique of the utilitarian vision of an engineered society. To this end, she presents in the first part of her deliberately schematic story three characters, childhood friends, who seem to represent Kant's three-part conception of the human subject: Victor Frankenstein, the forces of theoretical reason or "natural philosophy"; Henry Clerval, the forces of practical reason or "the moral relations of things"; and Elizabeth Lavenza, that aesthetic judgment - "the aerial creation of the poets"-which, according to Kant, is "a suitable mediating link connecting the realm of the concept of nature and that of the concept of freedom $\ldots$ (which) promotes . . moral feeling" $(F$, pp. 37,36$) .{ }^{26}$

This three-part subject does not operate harmoniously in Frankenstein. That Henry Clerval, associated as he is with practical reason, should have as his "design ... to visit India, in the belief that he had in his knowledge of its various languages, and in the views he had taken of its society, the means of materially assisting the progress of European colonization and trade" is proof of this, as well as part of the incidental imperialist sentiment that I speak of above (F, pp. 151-52). I should perhaps point out that the language here is entrepreneurial rather than missionary:

He came to the university with the design of making himself complete master of the Oriental languages, as thus he should open a field for the plan of life he had marked out for himself. Resolved to pursue no inglorious career, he turned his eyes towards the East as affording scope for his spirit of enterprise. The Persian, Arabic, and Sanskrit languages engaged his attention. $[F$, pp. 66-67]

But it is of course Victor Frankenstein, with his strange itinerary of obsession with natural philosophy, who offers the strongest demonstration that the multiple perspectives of the three-part Kantian subject cannot co-operate harmoniously. Frankenstein creates a putative human subject out of natural philosophy alone. According to his own miscued summation: 
"In a fit of enthusiastic madness I created a rational creature" $(F$, p. 206). It is not at all farfetched to say that Kant's categorical imperative can most easily be mistaken for the hypothetical imperative-a command to ground in cognitive comprehension what can be apprehended only by moral will-by putting natural philosophy in the place of practical reason.

I should hasten to add here that just as readings such as this one do not necessarily accuse Charlotte Brontë the named individual of harboring imperialist sentiments, so also they do not necessarily commend Mary Shelley the named individual for writing a successful Kantian allegory. The most I can say is that it is possible to read these texts, within the frame of imperialism and the Kantian ethical moment, in a politically useful way. Such an approach presupposes that a "disinterested" reading attempts to render transparent the interests of the hegemonic readership. (Other "political" readings - for instance, that the monster is the nascent working class - can also be advanced.)

Frankenstein is built in the established epistolary tradition of multiple frames. At the heart of the multiple frames, the narrative of the monster (as reported by Frankenstein to Robert Walton, who then recounts it in a letter to his sister) is of his almost learning, clandestinely, to be human. It is invariably noticed that the monster reads Paradise Lost as true history. What is not so often noticed is that he also reads Plutarch's Lives, "the histories of the first founders of the ancient republics," which he compares to "the patriarchal lives of my protectors" ( $F$, pp. 123, 124). And his education comes through "Volney's Ruins of Empires," which purported to be a prefiguration of the French Revolution, published after the event and after the author had rounded off his theory with practice $(F$, p. 113). It is an attempt at an enlightened universal secular, rather than a Eurocentric Christian, history, written from the perspective of a narrator "from below," somewhat like the attempts of Eric Wolf or Peter Worsley in our own time. ${ }^{27}$

This Caliban's education in (universal secular) humanity takes place through the monster's eavesdropping on the instruction of an ArielSafie, the Christianized "Arabian" to whom "a residence in Turkey was abhorrent" ( $F$, p. 121). In depicting Safie, Shelley uses some commonplaces of eighteenth-century liberalism that are shared by many today: Safie's Muslim father was a victim of (bad) Christian religious prejudice and yet was himself a wily and ungrateful man not as morally refined as her (good) Christian mother. Having tasted the emancipation of woman, Safie could not go home. The confusion between "Turk" and "Arab" has its counterpart in present-day confusion about Turkey and Iran as "Middle Eastern" but not "Arab."

Although we are a far cry here from the unexamined and covert axiomatics of imperialism in Jane Eyre, we will gain nothing by celebrating the time-bound pieties that Shelley, as the daughter of two antievangelicals, produces. It is more interesting for us that Shelley differentiates the 
Other, works at the Caliban/Ariel distinction, and cannot make the monster identical with the proper recipient of these lessons. Although he had "heard of the discovery of the American hemisphere and wept with Safie over the helpless fate of its original inhabitants," Safie cannot reciprocate his attachment. When she first catches sight of him, "Safie, unable to attend to her friend [Agatha], rushed out of the cottage" ( $F$, pp. 114 [my emphasis], 129).

In the taxonomy of characters, the Muslim-Christian Safie belongs with Rhys' Antoinette/Bertha. And indeed, like Christophine the good servant, the subject created by the fiat of natural philosophy is the tangential unresolved moment in Frankenstein. The simple suggestion that the monster is human inside but monstrous outside and only provoked into vengefulness is clearly not enough to bear the burden of so great a historical dilemma.

At one moment, in fact, Shelley's Frankenstein does try to tame the monster, to humanize him by bringing him within the circuit of the Law. $\mathrm{He}$ "repair[s] to a criminal judge in the town and ... relate[s his] history briefly but with firmness"- the first and disinterested version of the narrative of Frankenstein-"marking the dates with accuracy and never deviating into invective or exclamation.... When I had concluded my narration I said, 'This is the being whom I accuse and for whose seizure and punishment I call upon you to exert your whole power. It is your duty as a magistrate' " $(F$, pp. 189, 190). The sheer social reasonableness of the mundane voice of Shelley's "Genevan magistrate" reminds us that the absolutely Other cannot be selfed, that the monster has "properties" which will not be contained by "proper" measures:

"I will exert myself [he says], and if it is in my power to seize the monster, be assured that he shall suffer punishment proportionate to his crimes. But I fear, from what you have yourself described to be his properties, that this will prove impracticable; and thus, while every proper measure is pursued, you should make up your mind to disappointment." $[F$, p. 190]

In the end, as is obvious to most readers, distinctions of human individuality themselves seem to fall away from the novel. Monster, Frankenstein, and Walton seem to become each others' relays. Frankenstein's story comes to an end in death; Walton concludes his own story within the frame of his function as letter writer. In the narrative conclusion, he is the natural philosopher who learns from Frankenstein's example. At the end of the text, the monster, having confessed his guilt toward his maker and ostensibly intending to immolate himself, is borne away on an ice raft. We do not see the conflagration of his funeral pile-the selfimmolation is not consummated in the text: he too cannot be contained by the text. In terms of narrative logic, he is "lost in darkness and distance" 
( $F$, p. 211)-these are the last words of the novel-into an existential temporality that is coherent with neither the territorializing individual imagination (as in the opening of Jane Eyre) nor the authoritative scenario of Christian psychobiography (as at the end of Brontë's work). The very relationship between sexual reproduction and social subject-productionthe dynamic nineteenth-century topos of feminism-in-imperialism-remains problematic within the limits of Shelley's text and, paradoxically, constitutes its strength.

Earlier, I offered a reading of woman as womb holder in Frankenstein. I would now suggest that there is a framing woman in the book who is neither tangential, nor encircled, nor yet encircling. "Mrs. Saville," "excellent Margaret," "beloved Sister" are her address and kinship inscriptions $(F$, pp. 15, 17, 22). She is the occasion, though not the protagonist, of the novel. She is the feminine subject rather than the female individualist: she is the irreducible recipient-function of the letters that constitute Frankenstein. I have commented on the singular appropriative hermeneutics of the reader reading with Jane in the opening pages of Jane Eyre. Here the reader must read with Margaret Saville in the crucial sense that she must intercept the recipient-function, read the letters as recipient, in order for the novel to exist. ${ }^{28}$ Margaret Saville does not respond to close the text as frame. The frame is thus simultaneously not a frame, and the monster can step "beyond the text" and be "lost in darkness." Within the allegory of our reading, the place of both the English lady and the unnamable monster are left open by this great flawed text. It is satisfying for a postcolonial reader to consider this a noble resolution for a nineteenthcentury English novel. This is all the more striking because, on the anecdotal level, Shelley herself abundantly "identifies" with Victor Frankenstein. ${ }^{29}$

I must myself close with an idea that I cannot establish within the limits of this essay. Earlier I contended that Wide Sargasso Sea is necessarily bound by the reach of the European novel. I suggested that, in contradistinction, to reopen the epistemic fracture of imperialism without succumbing to a nostalgia for lost origins, the critic must turn to the archives of imperialist governance. I have not turned to those archives in these pages. In my current work, by way of a modest and inexpert "reading" of "archives," I try to extend, outside of the reach of the European novelistic tradition, the most powerful suggestion in Wide Sargasso Sea: that Jane Eyre can be read as the orchestration and staging of the selfimmolation of Bertha Mason as "good wife." The power of that suggestion remains unclear if we remain insufficiently knowledgeable about the history of the legal manipulation of widow-sacrifice in the entitlement of the British government in India. I would hope that an informed critique of imperialism, granted some attention from readers in the First World, will at least expand the frontiers of the politics of reading. 
1. My notion of the "worlding of a world" upon what must be assumed to be uninscribed earth is a vulgarization of Martin Heidegger's idea; see "The Origin of the Work of Art," Poetry, Language, Thought, trans. Albert Hofstadter (New York, 1977), pp. 17-87.

2. See Charlotte Brontë, Jane Eyre (New York, 1960); all further references to this work, abbreviated $J E$, will be included in the text.

3. See Jean Rhys, Wide Sargasso Sea (Harmondsworth, 1966); all further references to this work, abbreviated WSS, will be included in the text. And see Mary Shelley, Frankenstein; or, The Modern Prometheus (New York, 1965); all further references to this work, abbreviated $F$, will be included in the text.

4. I have tried to do this in my essay "Unmaking and Making in To the Lighthouse," in Women and Language in Literature and Society, ed. Sally McConnell-Ginet, Ruth Borker, and Nelly Furman (New York, 1980), pp. 310-27.

5. As always, I take my formula from Louis Althusser, "Ideology an Ideological State Apparatuses (Notes towards an Investigation)," "Lenin and Philosophy" and Other Essays, trans. Ben Brewster (New York, 1971), pp. 127-86. For an acute differentiation between the individual and individualism, see V. N. Vološinov, Marxism and the Philosophy of Language, trans. Ladislav Matejka and I. R. Titunik, Studies in Language, vol. 1 (New York, 1973), pp. 93-94 and 152-53. For a "straight" analysis of the roots and ramifications of English "individualism," see C. B. MacPherson, The Political Theory of Possessive Individualism: Hobbes to Locke (Oxford, 1962). I am grateful to Jonathan Rée for bringing this book to my attention and for giving a careful reading of all but the very end of the present essay.

6. I am constructing an analogy with Homi Bhabha's powerful notion of "not-quite/ not-white" in his "Of Mimicry and Man: The Ambiguity of Colonial Discourse," October 28 (Spring 1984): 132. I should also add that I use the word "native" here in reaction to the term "Third World Woman." It cannot, of course, apply with equal historical justice to both the West Indian and the Indian contexts nor to contexts of imperialism by transportation.

7. See Roberto Fernández Retamar, "Caliban: Notes towards a Discussion of Culture in Our America," trans. Lynn Garafola, David Arthur McMurray, and Robert Márquez, Massachusetts Review 15 (Winter-Spring 1974): 7-72; all further references to this work, abbreviated " $\mathrm{C}$," will be included in the text.

8. See José Enrique Rodó, Ariel, ed. Gordon Brotherston (Cambridge, 1967).

9. For an elaboration of "an inaccessible blankness circumscribed by an interpretable text," see my "Can the Subaltern Speak?" Marxist Interpretations of Culture, ed. Cary Nelson (Urbana, Ill., forthcoming).

10. See Elizabeth Fox-Genovese, "Placing Women's History in History," New Left Review 133 (May-June 1982): 5-29.

11. Rudolph Ackerman, The Repository of Arts, Literature, Commerce, Manufactures, Fashions, and Politics, (London, 1823), p. 310.

12. See Terry Eagleton, Myths of Power: A Marxist Study of the Brontës (London, 1975); this is one of the general presuppositions of his book.

13. See Sandra M. Gilbert and Susan Gubar, The Madwoman in the Attic: The Woman Writer and the Nineteenth-Century Literary Imagination (New Haven, Conn., 1979), pp. 36062.

14. Immanuel Kant, Critique of Practical Reason, The "Critique of Pure Reason," the "Critique of Practical Reason" and Other Ethical Treatises, the "Critique of Judgement," trans. J. M. D. Meiklejohn et al. (Chicago, 1952), pp. 328, 326.

15. I have tried to justify the reduction of sociohistorical problems to formulas or propositions in my essay "Can the Subaltern Speak?" The "travesty" I speak of does not befall the Kantian ethic in its purity as an accident but rather exists within its lineaments as a possible supplement. On the register of the human being as child rather than heathen, my formula can be found, for example, in "What Is Enlightenment?" in Kant, "Foundations of the Metaphysics of Morals," "What Is Enlightenment?" and a Passage from "The Metaphysics of Morals," trans. and ed. Lewis White Beck (Chicago, 1950). I have profited from discussing Kant with Jonathan Rée. 
16. Jean Rhys, in an interview with Elizabeth Vreeland, quoted in Nancy Harrison, An Introduction to the Writing Practice of Jean Rhys: The Novel as Women's Text (Rutherford, $\mathrm{N}$. J., forthcoming). This is an excellent, detailed study of Rhys.

17. See Louise Vinge, The Narcissus Theme in Western European Literature Up to the Early Nineteenth Century, trans. Robert Dewsnap et al. (Lund, 1967), chap. 5.

18. For a detailed study of this text, see John Brenkman, "Narcissus in the Text," Georgia Review 30 (Summer 1976): 293-327.

19. See, e.g., Thomas F. Staley, Jean Rhys: A Critical Study (Austin, Tex. 1979), pp. 108-16; it is interesting to note Staley's masculist discomfort with this and his consequent dissatisfaction with Rhys' novel.

20. I have tried to relate castration and suppressed letters in my "The Letter As Cutting Edge," in Literature and Psychoanalysis; The Question of Reading: Otherwise, ed. Shoshana Felman (New Haven, Conn., 1981), pp. 208-26.

21. This is the main argument of my "Can the Subaltern Speak?"

22. See Barbara Johnson, “My Monster/My Self," Diacritics 12 (Summer 1982): 2-10.

23. See George Levine, The Realistic Imagination: English Fiction from Frankenstein to Lady Chatterley (Chicago, 1981), pp. 23-35.

24. Consult the publications of the Feminist International Network for the best overview of the current debate on reproductive technology.

25. For the male fetish, see Sigmund Freud, "Fetishism," The Standard Edition of the Complete Psychological Works of Sigmund Freud, ed. and trans. James Strachey et al., 24 vols. (London, 1953-74), 21:152-57. For a more "serious" Freudian study of Frankenstein, see Mary Jacobus, "Is There a Woman in This Text?" New Literary History 14 (Autumn 1982): 117-41. My "fantasy" would of course be disproved by the "fact" that it is more difficult for a woman to assume the position of fetishist than for a man; see Mary Ann Doane, "Film and the Masquerade: Theorising the Female Spectator," Screen 23 (Sept.-Oct. 1982): 74-87.

26. Kant, Critique of Judgement, trans. J. H. Bernard (New York, 1951), p. 39.

27. See [Constantin François Chasseboeuf de Volney], The Ruins; or, Meditations on the Revolutions of Empires, trans. pub. (London, 1811). Johannes Fabian has shown us the manipulation of time in "new" secular histories of a similar kind; see Time and the Other: How Anthropology Makes Its Object (New York, 1983). See also Eric R. Wolf, Europe and the People without History (Berkeley and Los Angeles, 1982), and Peter Worsley, The Third World, 2d ed. (Chicago, 1973); I am grateful to Dennis Dworkin for bringing the latter book to my attention. The most striking ignoring of the monster's education through Volney is in Gilbert's otherwise brilliant "Horror's Twin: Mary Shelley's Monstrous Eve," Feminist Studies 4 (June 1980): 48-73. Gilbert's essay reflects the absence of race-determinations in a certain sort of feminism. Her present work has most convincingly filled in this gap; see, e.g., her recent piece on H. Rider Haggard's She ("Rider Haggard's Heart of Darkness," Partisan Review 50, no. 3 [1983]: 444-53).

28. "A letter is always and $a$ priori intercepted, . . . the 'subjects' are neither the senders nor the receivers of messages. . . . The letter is constituted . . by its interception" (Jacques Derrida, "Discussion," after Claude Rabant, "Il n'a aucune chance de l'entendre," in Affranchissement: Du transfert et de la lettre, ed. René Major [Paris, 1981], p. 106; my translation). Margaret Saville is not made to appropriate the reader's "subject" into the signature of her own "individuality."

29. The most striking "internal evidence" is the admission in the "Author's Introduction" that, after dreaming of the yet-unnamed Victor Frankenstein figure and being terrified (through, yet not quite through, him) by the monster in a scene she later reproduced in Frankenstein's story, Shelley began her tale "on the morrow ... with the words 'It was on a dreary night of November' " $(F, \mathrm{p}$. xi). Those are the opening words of chapter 5 of the finished book, where Frankenstein begins to recount the actual making of his monster (see F, p. 56). 